\title{
A Potentized Homeopathic Drug, Arsenicum Album 200, Can Ameliorate Genotoxicity Induced by Repeated Injections of Arsenic Trioxide in Mice
}

\author{
P. BAnerJee ${ }^{1}$, S. J. Biswas ${ }^{1}$, P. Belon ${ }^{2}$ and A. R. Khuda-Bukhsh ${ }^{1,3}$ \\ Addresses of authors: ${ }^{1}$ Department of Zoology, University of Kalyani, Kalyani 741235, India; ${ }^{2}$ Boiron Lab, 69110 Sainte-Foy- \\ Les-Lyon, France; ${ }^{3}$ Corresponding author: Tel.: +91 3325828750 x 315 (O)/2582 8768 (R); fax: + 9133 2582 8282; E-mail: \\ prof_arkb@yahoo.co.in; khudabukhsh_48@rediffmail.com
}

With 6 figures and 1 table

Received for publication October 22, 2006

\begin{abstract}
Summary
Groundwater arsenic contamination has become a menacing global problem. No drug is available until now to combat chronic arsenic poisoning. To examine if a potentized homeopathic remedy, Arsenicum Album-200, can effectively combat chronic arsenic toxicity induced by repeated injections of Arsenic trioxide in mice, the following experimental design was adopted. Mice (Mus musculus) were injected subcutaneously with $0.016 \%$ arsenic trioxide at the rate of $1 \mathrm{ml} / 100 \mathrm{~g}$ body weight, at an interval of 7 days until they were killed at day $30,60,90$ or 120 and were divided into three groups: (i) one receiving a daily dose of Arsenicum Album-200 through oral administration, (ii) one receiving the same dose of diluted succussed alcohol (Alcohol-200) and (iii) another receiving neither drug, nor succussed alcohol. The remedy or the placebo, as the case may be, was fed from the next day onwards after injection until the day before the next injection, and the cycle was repeated until the mice were killed. Two other control groups were also maintained: one receiving only normal diet, and the other receiving normal diet and succussed alcohol. Several toxicity assays, such as cytogenetical (chromosome aberrations, micronuclei, mitotic index, sperm head anomaly) and biochemical (acid and alkaline phosphatases, lipid peroxidation), were periodically made. Compared with controls, the drug fed mice showed reduced toxicity at statistically significant levels in respect of all the parameters studied, thereby indicating protective potentials of the homeopathic drug against chronic arsenic poisoning.
\end{abstract}

\section{Introduction}

Arsenic compounds are perceived as weak mutagens in bacterial and animal cells. However they are reported to produce clastogenic and aneugenic effects and induce gene amplification, cellular transformation, DNA cross-links and DNA strand breaks in animal cells (Basu et al., 2001). Liver injury induced by chemicals and its recovery processes have been extensively studied to understand many cytotoxicological problems (Zimmerman, 1978; Plaa et al., 1991). Many toxic chemicals, including arsenic trioxide, have earlier been reported to cause degenerative changes in the liver. In case of acute exposure, hepatocellular necrosis or hepatobilliary dysfunction results, often followed by lipid accumulation (Plaa et al., 1991). Lipid peroxidation along with elevated liver triglycer- ides has been reported to occur after administration of tetrachloroethanol, chloroform and carbon tetra chloride (Tomokuni, 1970). Moreover associated with the toxicity level of liver tissue are the activities of some enzymes like acid and alkaline phosphatases.

In a series of our earlier studies (Mitra et al., 1998, 1999; Datta et al., 1999; Kundu et al., 2000a,b; Mallick et al., 2003), various effects in regard to cytogenetical and biochemical changes induced by a single ip dose of $0.004 \%$ Arsenic trioxide at the rate of $1 \mathrm{ml} / 100 \mathrm{~g}$ of body weight had been studied in mice and it was revealed that a potentized homeopathic remedy, Arsenicum Album 30, derived from arsenic trioxide by homeopathic procedure of succussion and dilution, could effectively combat arsenic trioxide induced toxicity in mice. In the present investigation, we intended to examine if a higher potency, which in homeopathic doctrine, should be expected to have stronger efficacy, was able to combat chronic arsenic toxicity induced by repeated injections of $0.016 \%$ arsenic trioxide at an interval of 7 days in mice before being killed at day $30,60,90$ and day 120 for conducting various cytogenetical and toxicity marker assays.

\section{Materials and Methods}

Swiss albino mice (Mus musculus) were reared and maintained in the animal house of the Department of Zoology (with clearance from the University Ethical Committee and under the supervision of the Animal Welfare Committee), University of Kalyani, for the purpose of conducting the present investigation. Mice were provided food (wheat, gram and powdered milk) and water ad libitum and kept in hygienic condition. A group of 30 healthy mice weighing between 25 and $30 \mathrm{~g}$ were used for each of the fixation intervals. Each group of 30 mice were sub-divided into five different sets consisting of six mice each, that served as (i) normal, (ii) normal + succussed alcohol (Alc-200), (iii) $\mathrm{As}_{2} \mathrm{O}_{3}$, (iv) $\mathrm{As}_{2} \mathrm{O}_{3}+$ Alc 200 and (v) $\mathrm{As}_{2} \mathrm{O}_{3}+$ Ars alb-200 fed series. The first set of mice (group-I, normal negative control) was allowed normal low protein diet. The second set of mice (group II) was fed Alc-200 with normal low protein diet. The third set of mice (group-III) was injected $0.016 \% \mathrm{As}_{2} \mathrm{O}_{3}$. The fourth set of mice (group-IV, positive control) was injected $0.016 \%$ $\mathrm{As}_{2} \mathrm{O}_{3}$ and fed Alc-200 (as the 'vehicle' of the drug was in ethyl alcohol) until they were killed. The fifth set of mice (group V) was injected with $0.016 \% \mathrm{As}_{2} \mathrm{O}_{3}$ as in group-III, but was also 
fed Ars alb-200 once daily until they were killed at day 30, 60, 90 and 120.

\section{Preparation of the potentized form of the drug}

The potentized form of the homeopathic drug, Ars alb-200, and the placebo, Alc-200, prepared as per the standard procedure of homeopathic principle of 'succussions and dilution', were kindly donated by Boiron Lab, Lyon, France. $1 \mathrm{ml}$ each of Ars alb-200 and Alc-200 was diluted separately with $20 \mathrm{ml}$ of double distilled water to make the stock solution of Ars alb-200 and Alc-200 respectively.

\section{Feeding procedure and dosage}

Each mouse was fed a daily dose of one drop $(0.06 \mathrm{ml})$ of stock solution of Ars alb-200 or Alc-200, as the case may be, through gavage with the aid of a fine pipe.

\section{Laboratory methodology}

\section{Cytogenetical assay}

The standard and widely accepted cytogenetical protocols like assay of chromosome aberrations (CA), micronuclei (MN), mitotic index (MI) and sperm head anomaly (SHA) have been adopted in the present study.

Mice were injected intraperitonially with $0.03 \%$ colchicine at the rate of $1 \mathrm{ml} / 100 \mathrm{~g}$ body weight, $90 \mathrm{~min}$ before sacrifice. Marrow of the femur was flushed in $1 \%$ sodium citrate solution at $37^{\circ} \mathrm{C}$ and fixed in acetic acid/ethanol (1:3). Slides were prepared by the conventional flame drying technique previously described (Biswas et al., 2004) followed by Giemsa staining for scoring bone marrow chromosome aberrations. Chromosome aberrations have been pooled into two categories: the 'major' type comprising aberrations like break, fragment, ring, etc. and the 'other' types comprising less significant aberrations like gap, erosion, etc. A total of 300 bone marrow cells were observed, 50 from each of six mice of a set.

For micronucleus preparation, a part of the suspension of bone marrow cells in $1 \%$ sodium citrate was smeared on clean grease free slides, briefly fixed in methanol and subsequently stained with May-Grunwald followed by Giemsa (Schmid, 1976). Approximately 3000 bone marrow cells, comprising both polychromatic erythrocytes (PCE) and normochromatic erythrocytes (NCE) were scored and the ratios between PCE and NCE were calculated.

The MI was determined from the same slide which was scanned for $\mathrm{MN}$, and a total of 3000 cells were examined from each series. The non-dividing and dividing cells were recorded and their ratios ascertained.

For SHA, the technique of Wyrobek et al. (1984) was adopted with minor modifications. The epididymis of each side of mouse of control and treated sets was dissected out and its inner content squeezed out into $10 \mathrm{ml}$ of $0.87 \%$ normal saline separately. It was made free of fats, vas deferens and other tissues. The content was thoroughly shaken, the solution was filtered through a silken cloth and dropped on grease free clean slides. The slides were allowed to air dry and then stained by dilute Giemsa ( $1 \mathrm{ml}$ Giemsa in $10 \mathrm{ml}$ distilled water). 3000 sperm were examined in each series.

\section{Biochemical assays}

Mice were killed and their liver and spleen tissues were quickly isolated. Approximately $50 \mathrm{mg}$ of liver tissue and $20 \mathrm{mg}$ of spleen tissue diluted in $20 \mathrm{ml}$ of phosphate buffer were homogenized separately and centrifuged at $3000 \mathrm{~g}$ for $20 \mathrm{~min}$ in a cooling centrifuge (C24, Remi Instruments, Mumbai, India). Before carrying out the enzymatic estimations the quantitative estimation of total protein was made by the method of Lowry et al. (Lowry et al., 1951). To $0.1 \mathrm{ml}$ of the sample, $0.9 \mathrm{ml}$ of $0.1 \mathrm{~N} \mathrm{NaOH}$ was added. Then $5 \mathrm{ml}$ of alkaline solution was added to the sample solution followed by $0.5 \mathrm{ml}$ of Folin-Phenol reagent and after $30 \mathrm{~min}$ the extinction was read at $660 \mathrm{~nm}$ against an appropriate blank in spectrophotometer (Shimadzu; Double beam Spectrophotometer UV1700, Tokyo, Japan).

The lipid peroxidation activity was estimated from the supernatant by the method of Buege and Aust (1984). $1 \mathrm{ml}$ homogenate was mixed thoroughly with $2 \mathrm{ml}$ of TCA-TBA$\mathrm{HCl}(15 \% \mathrm{w} / \mathrm{v} \mathrm{TCA}$ and $0.375 \% \mathrm{w} / \mathrm{v}$ TBA in $0.25 \mathrm{~N} \mathrm{HCl})$. The absorbance of the sample was determined at $535 \mathrm{~nm}$ in a double beam spectrophotometer against a suitable blank. The malonaldehyde concentration of the sample was calculated by using extinction coefficient of $1.56 \times 10^{5} \mathrm{M}^{-1} \mathrm{~cm}^{-1}$.

For the study of acid and alkaline phosphatases the method of Walter and Schutt (1974) was followed. For acid phosphatase, to $0.2 \mathrm{ml}$ tissue homogenate, $1 \mathrm{ml}$ of acid buffer was added. It was thoroughly mixed and incubated at $37^{\circ} \mathrm{C}$ for $30 \mathrm{~min}$. Then $2 \mathrm{ml}$ of $0.1 \mathrm{~N} \mathrm{NaOH}$ was added to the mixture. The absorbance was measured at $405 \mathrm{~nm}$ against the standard.

For alkaline phosphatase activity, $0.05 \mathrm{ml}$ homogenate was mixed with $2 \mathrm{ml}$ alkaline buffer. It was incubated at $37^{\circ} \mathrm{C}$ for $30 \mathrm{~min}$, then $10 \mathrm{ml}$ of $0.05 \mathrm{~N} \mathrm{NaOH}$ was added and the absorbance was measured at $405 \mathrm{~nm}$ against a blank.

\section{Determination of arsenic content}

The arsenic contents in the liver and spleen tissues were measured by the standardized atomic absorption spectrometry (Locke, 1979; Nurenberg, 1984). $50 \mathrm{mg}$ of liver tissue, $25 \mathrm{mg}$ of spleen tissue were allowed to fix in formaldehyde and dried at $150^{\circ} \mathrm{C}$ for $20 \mathrm{~min}$ to evaporate the formaldehyde. Next, samples were transferred inside volumetric flasks, which had been washed with $1: 1 \mathrm{HNO}_{3}$ and $\mathrm{H}_{2} \mathrm{SO}_{4}$ solution. The samples were digested with a nitric and sulphuric acid mixture (3:1) inside a digestion chamber at $150^{\circ} \mathrm{C}$ for $20 \mathrm{~min}$. Until a small volume of the sample was obtained, the flasks were capped and the enclosed samples were boiled. Digested samples were filtered and diluted up to $25 \mathrm{ml}$ with double distilled water. The same double distilled water was used as blank, and readings were taken in a Perkin-Elmer model of the atomic absorption spectrometer.

\section{Statistical analysis}

The significance test between the normal and carcinogen treated series was carried out as per the routine Student's $t$-test method (Fisher and Yates, 1963). During biochemical estimation and haematological studies the 'observer' was kept 'blinded' of the animal whether it belonged to 'treated' or 'control' group, to remove any 'bias' in observation and 


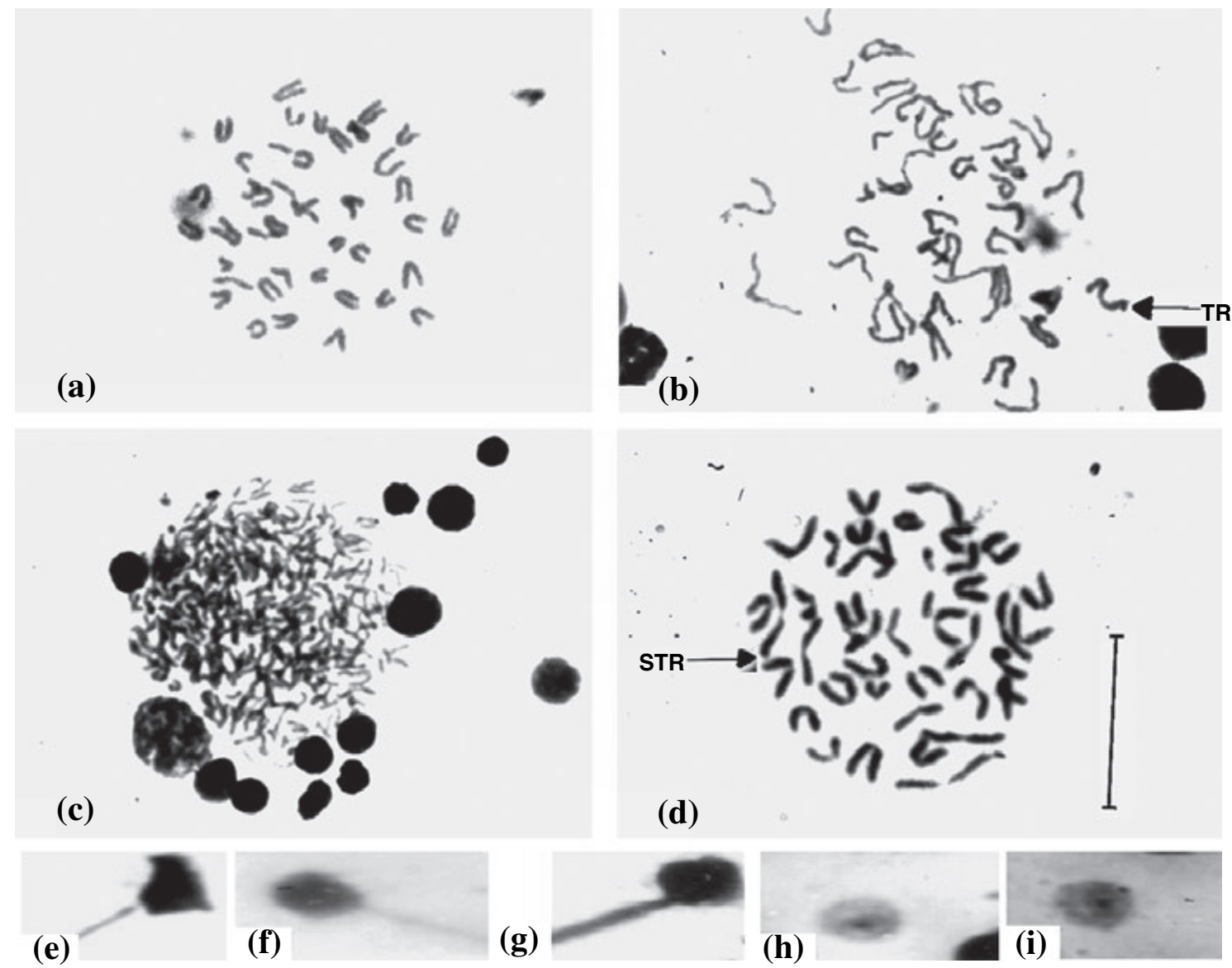

Fig. 1. Explanation of Photomicrographs: (a-d) Photomicrographs of metaphase complements: (a) typical normal spread, (b) showing translocation, (c) showing polyploidy and (d) showing stretching. Photomicrographs of normal sperm head (e) and abnormal sperm heads (f-g). Bone marrow smears showing micronucleated erythrocytes $(\mathrm{h}-\mathrm{i})$. Bar indicates $10 \mu \mathrm{m}$.

thereby uniformity was maintained in scoring data of both treated and control sets of mice.

\section{Results}

\section{Cytogenetical studies}

Compared with normal metaphase complement (Fig. 1a) which did not normally reveal any aberration, various types of $\mathrm{CA}$ of both major and minor nature (Fig. 1b-d) were encountered in certain metaphase plates of mice that received

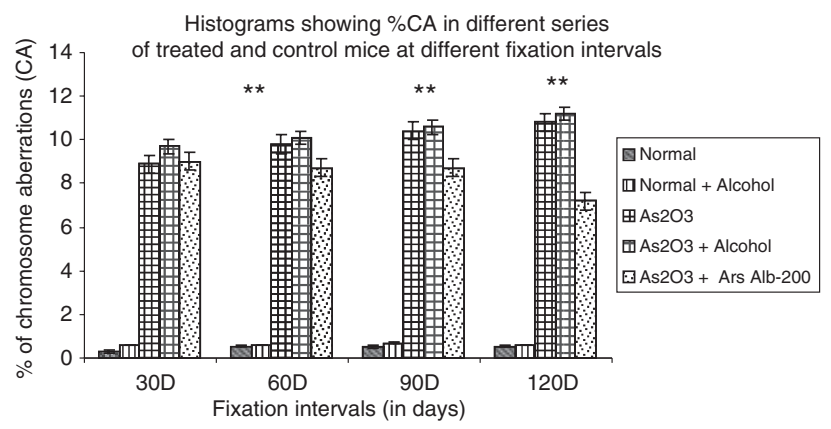

Fig. 2. Histogram showing \% chromosome aberrations (CA) in different series of treated and control mice at different fixation intervals.
$\mathrm{As}_{2} \mathrm{O}_{3}$ treatments. The total frequencies of CA were found to be maximum in $\mathrm{As}_{2} \mathrm{O}_{3}+$ alcohol fed mice. There was, however, a much less incidence of CA in the Ars Alb-200 fed group of mice, indicating significant amount of suppression of CA in this series when compared with the Alc-200 fed controls at all fixation intervals (Fig. 2). There were also some minor aberrations found in negligible quantity in the normal group of mice.

\section{Sperm head anomaly}

Quite a high incidence of sperm showing some form of abnormal head morphology has been recorded in the different treatment series. In Ars Alb-200 fed mice, the percentage of sperm with abnormal head morphology (Fig. 1e-g) was considerably reduced and the differences with regard to controls were statistically significant at day 60, 90 and 120 (Fig. 3).

\section{Mitotic index}

In the drug-fed mice, there was an increase in MI frequencies, which was statistically significant at all the fixation intervals (Fig. 4). On the contrary, there was a gradual reduction in the frequencies of $\mathrm{MI}$ in the arsenic trioxide injected group. 


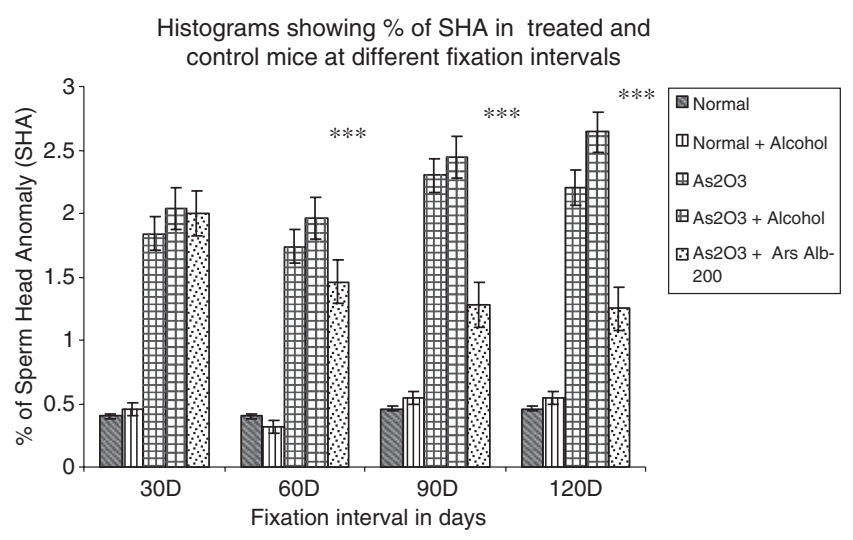

Fig. 3. Histogram showing \% sperm head anomaly (SHA) in different series of treated and control mice at different fixation intervals.

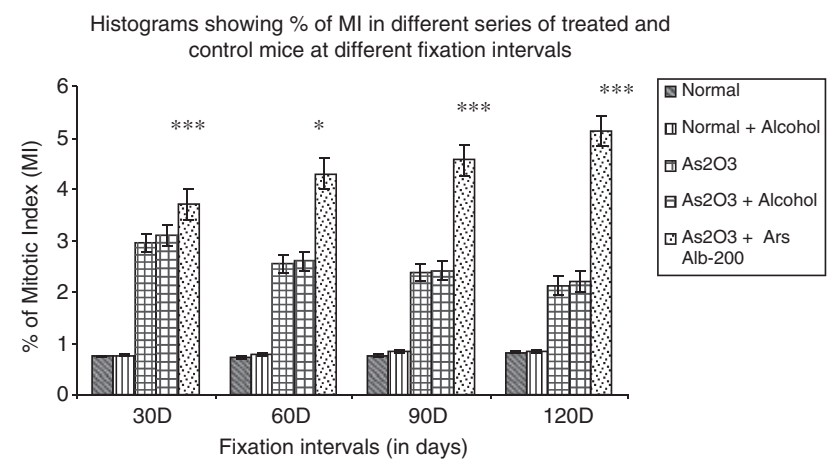

Fig. 4. Histogram showing \% mitotic index (MI) in different series of treated and control mice at different fixation intervals.

\section{Micronucleated erythrocytes}

Data on occurrence of $\mathrm{MN}$ in normochromatic (NCE) and polychromatic (PCE) erythrocytes have been provided (Fig. 5) and also representative photomicrographs have been shown (Fig. 1h-i). The percentages of MN were the highest in $\mathrm{As}_{2} \mathrm{O}_{3}+$ alcohol fed mice at all the fixation intervals. The least number of MN was noticed in mice fed with Ars Alb-200, at all fixations of interval.

Histograms showing \% of $\mathrm{MN}$ in different series of treated and control mice at different fixation intervals

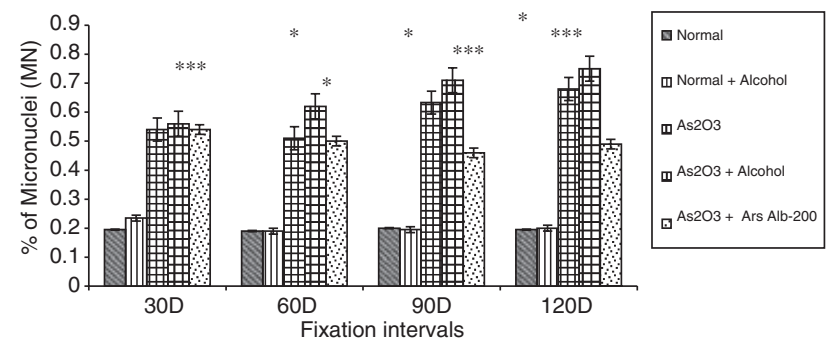

Fig. 5. Histogram showing \% micronuclei (MN) in different series of treated and control mice at different fixation intervals.

\section{Biochemical assay}

\section{Acid phosphatase activity}

The acid phosphatase activity in the $\mathrm{As}_{2} \mathrm{O}_{3}+$ Alc-200 fed series was significantly increased in both the liver and spleen tissues at all fixation intervals when compared with normal controls (Table 1). The AcP activity in the liver of $\mathrm{As}_{2} \mathrm{O}_{3}+$ Ars Alb-200 fed mice was significantly decreased at all fixation intervals but the decrease was not statistically significant at day 30. Interestingly, the AcP activity in the liver tissue was found to be slightly higher than in the spleen at all fixation intervals except at day 90 .

\section{Alkaline phosphatase activity}

The AlkP activity in the $\mathrm{As}_{2} \mathrm{O}_{3}+$ Alc-200 fed series was notably increased in liver and spleen tissues at all fixation intervals when compared with the normal controls (Table 1). But the AlkP activity in liver of the drug fed mice was significantly decreased at all fixation intervals. However at day 90, the AlkP activity was found to be drastically increased in the spleen tissue but it was decreased at day 120, the reason for which was not clearly understood. Interestingly enough, the activity of AlkP was found to be increased at day 120 in the liver tissues of drug fed mice.

\section{Lipid peroxidation activity}

LPO ( Table 1) was significantly decreased in drug fed series when compared with arsenic trioxide treated series at all fixation intervals in both the tissues. Although there was a general trend of reduction in the activity of LPO at all fixation intervals, the reduction in their activities was not to the same extent.

\section{Arsenic content}

The group treated with $\mathrm{As}_{2} \mathrm{O}_{3}+$ Alc-200 showed a significant elevation in arsenic deposition in both the liver and spleen tissues when compared with that of the drug fed group. However in the drug fed group, the arsenic content in the above organs was strikingly less, almost as low as in the controls (Fig. 6).

\section{Discussion}

In our earlier studies liver appeared to be one of the major organs in which arsenic caused considerable damages, tissue necrosis and other histological as well as biochemical changes (Mitra et al., 1998, 1999; Kundu et al., 2000a,b; Mallick et al., 2003). Liver damage as a consequence of arsenic poisoning has also been reported in human subjects (Guha Mazumder et al., 1997). Incidentally, intraperitoneal injections of serial dilutions of arsenic compounds (arsenicus anhydride), mainly in decimal potencies, have earlier been reported to increase arsenic elimination in varying amounts from blood of arsenic intoxicated rats through urine and faeces (Cazin et al., 1987; Linde et al., 1994). Similarly, the homeopathic remedy, Arsenicum Album-30, showed ameliorative changes in mice against a single dose injection of arsenic trioxide, in respect of various cytogenetical as well as biochemical protocols used (Mitra et al., 1998, 1999; Datta et al., 1999; Kundu et al., 2000a,b; Mallick et al., 2003). 


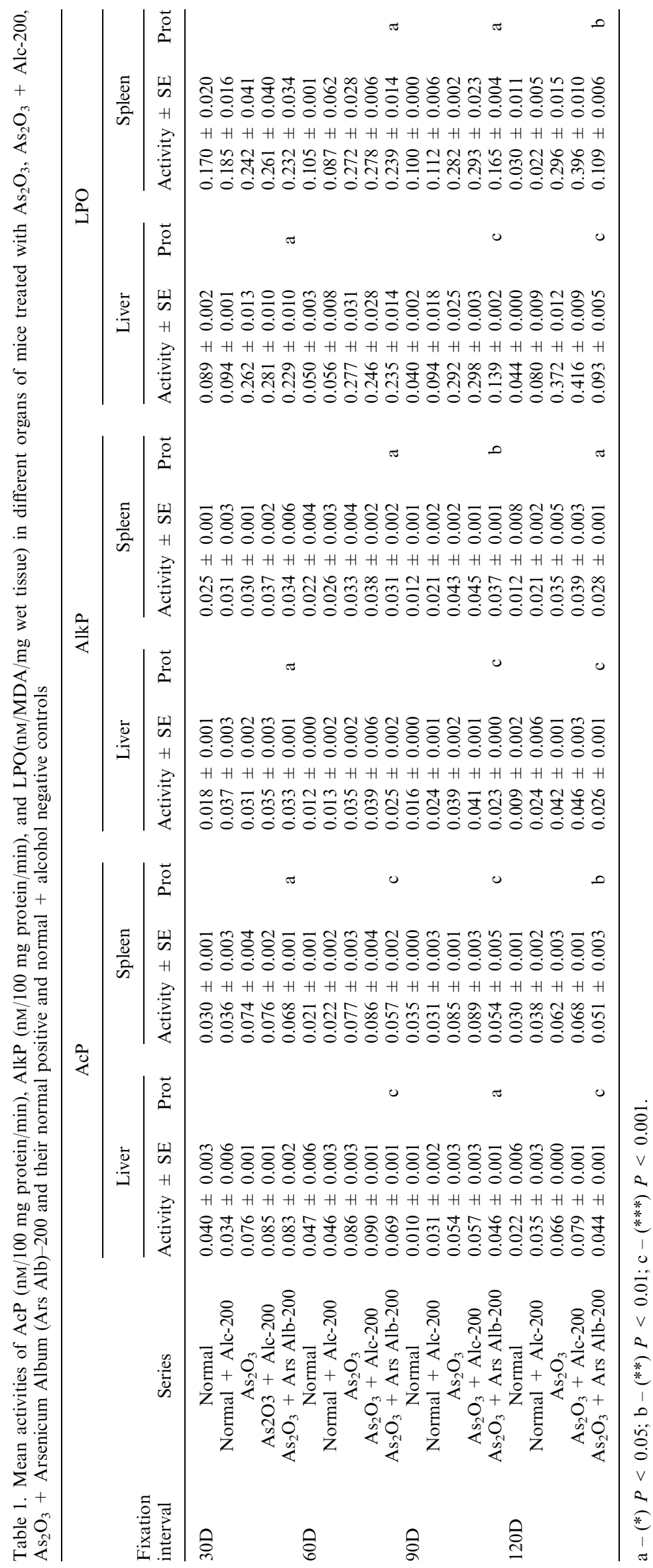




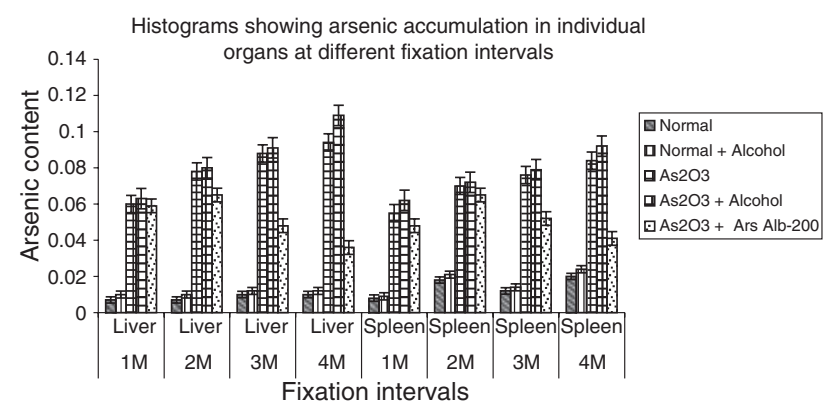

Fig. 6. Histogram showing arsenic accumulation in liver and spleen of treated and control mice at different fixation intervals.

In our present study also, oral administration of the homeopathic remedy Arsenicum Album 200 appeared to show protective potentials against arsenic trioxide induced chronic poisoning in mice, which is a significant finding having implications in favour of its possible human application in arsenic contaminated villages. In the drug fed series, there was a marked reduction in various types of chromosomal, nuclear and sperm head abnormalities, which would signify antigenotoxic effect of the homeopathic remedy. Similarly, the findings of elevated toxicity level shown by assay of different biomarkers in arsenic trioxide treated mice being significantly reduced in the drug fed series, would also testify that the drug also had visible anti-cytotoxic effects preventing tissue necrosis and subsequent damage in the liver. The ability of the remedy in causing palpable reduction in chromosomal and nuclear damage would clearly point to its ability to combat the mutagen-induced damage at the chromosomal and genomic level. Similarly, there was a marked increase in MI in the drug fed series, in contrast to the highly reduced frequency of MI in the arsenic trioxide treated mice, presumably in a bid to replenish lost or damaged blood cells as a result of the poison. The same trend was also visible in respect of the MN, which generally originated from broken chromosomes, which failed to move into daughter nuclei. Incidentally, MN provide an indirect measurement of the induction of structural CA's. The frequency of $\mathrm{MN}$ was strikingly increased in the arsenic trioxide treated mice, but was brought down significantly in the drug fed mice. All these changes would also support the anti-mutagenic role played by the homeopathic remedy, showing its impact at the molecular level.

The increase in the number of abnormal sperm in the arsenic trioxide treated mice would suggest that arsenic trioxide also had spermatotoxic effect, and the protection rendered by the administration of the homeopathic remedy would speak for their role in protecting the gonadal tissue as well. The process of lipid peroxidation is initiated by the attack of a free radical on unsaturated lipids and the resulting chain reaction is terminated by the production of lipid breakdown products, lipid, alcohol, aldehyde and malonaldehyde. Thus there is a cascade of peroxidative reaction which ultimately leads to the destruction of lipid and thus the liberation and quantification of malonaldehyde reflect the state of toxicity which may affect membrane structure (Biswas and Khuda-Bukhsh, 2004a,b; Biswas et al., 2005). In conformity with this, a gradual rise of LPO activity was noticed in arsenic trioxide injected series from day 30 to day 120 and a corresponding decrease in the drug fed mice, which will again lend support to the ability of the homeopathic remedy in combating the toxic effect of arsenic trioxide. The drug also appeared to show its protective ability with regard to LPO in spleen.

Acid and alkaline phosphatases have been directly implicated to the extent of cellular damage and toxicity (Timbrell, 1991; Khuda-Bukhsh, 1997, 2003), particularly of liver and cardiac tissue. The level increases mainly as a result of liver, bile duct or gall bladder dysfunction. In the present investigation, the homeopathic remedy brought forth appreciable reduction in the levels of phosphatase activities in the drug fed mice, which would again convincingly denote its ability to combat arsenic poisoning.

Incidentally, from the findings of the present study, a fairly strong correlation can be substantiated between modulations in the cytogenetical endpoints and the enzyme biomarkers, which were consistent in their expected pattern of expression, both in the arsenic trioxide treated series as well as in the drug fed series, depicting an overall positive influence of the remedy in ameliorating the toxic effects of arsenic trioxide in mice. Thus, the results of this investigations would also suggest that homeopathic remedies could also be tested for their possible positive role in amelioration of arsenic toxicity in other mammals as well, which may also be relevant in terms of its application in other domestic animals, particularly in areas reported to have groundwater arsenic contamination or else in diseases where the symptoms may tally with that of the homeopathic remedy. How the ultra low doses of the remedy, which are not theoretically expected to possess even a single molecule of the original drug substance, could bring about multiple changes in both cytogenetical and enzyme biomarkers, is rather unclear at the present state of our knowledge. Incidentally, Khuda-Bukhsh (Khuda-Bukhsh, 1997, 2003, 2006; Pathak et al., 2006) proposed a hypothesis that one mechanism through which the potentized homeopathic drugs act could be through regulation of expression of certain relevant genes, by acting as suitable 'molecular switch' with the ability to trigger a cascade of gene actions, as all the cytogenetical and biochemical markers tested are generally under the strict control of a specific genetic regulatory mechanism.

\section{Acknowledgements}

The work was supported by a grant from Boiron Lab, Lyon, France, to Prof. A.R. Khuda-Bukhsh, which is gratefully acknowledged.

\section{References}

Basu, A., J. Mahata, S. Gupta, and A. K. Giri, 2001: Genetic toxicology of a paradoxical human carcinogen, arsenic - a review. Mut. Res. 488, 171-194.

Biswas, S. J., and A. R. Khuda-Bukhsh, 2004a: Evaluation of protective potentials of a potentized hoemopathic drug, Chelidonium majus, during azo dye induced hepatocarcinogenesis in mice. Indian J. Exp. Biol. 42, 698-714.

Biswas, S. J., and A. R. Khuda-Bukhsh, 2004b: Evaluation of Protective Potential of a Crude Plant Extract (Chelidonium majus) Against p-Dimethylaminoazobenzene Induced Hepatocarcinogenesis in Mice. 7th International Symposium on Predictive Oncology and intervention strategies, Nice, France, Feb. 7-10. 
Biswas, S. J., S. Pathak, and A. R. Khuda-Bukhsh, 2004: Assessment of the genotoxic and cytotoxic potential of an antiepileptic drug Phenobarbital, in mice: a time course study. Mut. Res. 563, 1-11.

Biswas, S. J., S. Pathak, N. Bhattacharjee, and A. R. Khuda-Bukhsh, 2005: Efficacy of a potentized homeopathic drug, Carcinosin-200, fed alone and in combination with another drug, Chelidonium 200, in amelioration of $\mathrm{p}-\mathrm{DAB}$ induced hepatocarcinogenesis in mice. $\mathrm{J}$. Alt. Comp. Med. 11, 839-854.

Buege, J. A., and S. D. Aust, 1984: Microsomal lipid peroxidation. Methods Enzymol. 105, 302-310.

Cazin, J. C., M. Cazin, J. L. Gabroit, A. Chaoui, J. Boiron, and P. Belon, 1987: A study of the effect of decimal and centesimal dilutions of arsenic on the retention and mobilization of arsenic in the rat. Human Toxicol. 6, 315-320.

Datta, S., P. Mallick, and A. R. Khuda Bukhsh, 1999: Efficacy of a potentized homeopathic drug (Arsenicum Album- 30) in reducing genotoxic effects produced by arsenic trioxide in mice: II Comparative efficacy of an antibiotic actinomycin $\mathrm{D}$ alone and in combination with either of two microdoses. Comp. Ther. Med. 6, 156-163.

Fisher, R. A., and F. Yates, 1963: Statistical Tables for Biological, Agricultural and Medical Research, 6th edn. Oliver and Boyd, Edinburgh.

Guha Mazumder, D. N., J. Das Gupta, A. Santra, A. Pal, A. Ghose, and S. Sarkar, 1997: Non-cancer effects of chronic arsenicosis with special reference to liver damage. In: Aberthy, C. O., R. L. Calderon, and W. R. Chappel (eds), Arsenic: Exposure and Health Effects, pp.113-123. Chapman and Hall, London.

Khuda-Bukhsh, A. R., 1997: Potentized homeopathic drugs act through regulation of gene expression: a hypothesis to explain their mechanism and pathways of action in vivo. Comp. Ther. Med. 5, 43-46.

Khuda-Bukhsh, A. R., 2003: Towards understanding molecular mechanisms of action of homeopathic drugs: an overview. Mol. Cell. Biochem. 253, 339-345.

Khuda-Bukhsh, A. R., 2006: Laboratory research in homeopathy: pro. Integr. Cancer Ther. 5, 320-332.

Kundu, S. N., K. Mitra, and A .R. Khuda-Bukhsh, 2000a: Efficacy of a potentized homeopathic drug (Arsenicum Album-30) in reducing cytotoxic effects produced by arsenic trioxide in mice: III Enzymatic changes and recovery of tissue damage in liver. Comp. Ther. Med. 8, 76-81.

Kundu, S. N., K. Mitra, and A. R. Khuda-Bukhsh, 2000b: Efficacy of a potentized homeopathic drug (Arsenicum Album-30) in reducing cytotoxic effects produced by arsenic trioxide in mice: IV Pathological changes, protein profiles and content of DNA and RNA. Comp. Ther. Med. 8, 157-175.

Linde, K., W. B. Jonas, D. Melchart, F. Worku, H. Wagnert, and F. Eitel, 1994: Critical review and meta-analysis of serial agitated dilutions in experimental toxicology. Human Exp. Toxicol. 13, 481492.

Locke, J., 1979: The determination of eight elements in human liver tissue by flame atomic absorption spectrometry in sulphuric acid solution. Anal. Chem. Acta. 104, 225-231.

Lowry, O. H., N. J. Rosebrough, A. L. Farr, and R. J. Randall, 1951: Protein measurement with Folin-Phenol reagent. J. Biol. Chem. 193, 265-275.

Mallick, P., J. C. Mallick, B. Guha, and A. R. Khuda Bukhsh, 2003: Ameliorating effect of microdoses of a potentized homeopathic drug Arsenicum album, on arsenic induced toxicity in mice. BMC Comp. Alter. Med. 3, 7.

Mitra, K., S. N. Kundu, and A. R. Khuda-Bukhsh, 1998: Efficacy of a potentized homeopathic drug (Arsenicum Album-30) in reducing toxic effects produced by arsenic trioxide in mice: I On the rate of accumulation of arsenic in certain vital organs. Comp. Ther. Med. 6, 178-184

Mitra, K., S. N. Kundu, and A. R. Khuda-Bukhsh, 1999: Efficacy of a potentized homeopathic drug (Arsenicum Album- 30) in reducing toxic effects produced by arsenic trioxide in mice: II On alterations of body weight, tissue weight and total protein. Comp. Ther. Med. 7, 24-34.

Nurenberg, W. H., 1984: Voltametric trace analysis in ecological chemistry of toxic metals. Pure. Appl. Chem. 54, 853-878.

Pathak, S., J. K. Das, S. J. Biswas, and A. R. Khuda-Bukhsh, 2006: Protective potentials of a potentized homeopathic drug, Lycopodium-30, in ameliorating azo dye induced hepatocarcinogenesis in mice. Mol. Cell. Biochem. 285, 121-131.

Plaa, G. L., A. M. Amdun, J. Doull, and C. D. Klasser, 1991: Toxicology, The Basic Science of Poisons, 4th edn. Pergamon Press, UK.

Schmid, W., 1976: Principles and methods of detection. In: Hollaender, A.(ed.), Chemical Mutagens, pp.55. Plenum Press, New York.

Timbrell, J. A., 1991: Principles of Biochemical Toxicology. Taylor and Francis Publishing Co Inc, London.

Tomokuni, K., 1970: Studies on hepatoxicity induced by chlorinated hydrocarbons II. Lipid metabolism and absorption spectrum of microsomal lipid in mice exposed to 1.1.2.2-tetra chloroethane. Acta. Med. Okayama. 24, 315-322.

Walter, K., and C. Schutt, 1974: Acid and alkaline phosphatase in serum (Two point method). In: Bergmeyer, H. U. (ed.), Methods in Enzymatic Analysis, pp. 856-860. Academic Press, New York, USA.

Wyrobek, A. J., G. Watchmaker, and L. Gordon, 1984: Sperm morphology testing in mice. In: Kilbey, B. J., M. Legator, W. Nichols, and C. Ramel (eds), Handbook of Mutagenecity Test Procedures, pp. 733-750. Elsevier Science, Amsterdam.

Zimmerman, H. J., 1978: Hepatotoxicity. Appleton Century Crofts, New York. 
Copyright of Journal of Veterinary Medicine Series $A$ is the property of Blackwell Publishing Limited and its content may not be copied or emailed to multiple sites or posted to a listserv without the copyright holder's express written permission. However, users may print, download, or email articles for individual use. 